\title{
AVALIAÇÃO dO POTENCIAL DAS MÍDIAS SOCIAIS COMO FERRAMENTA DE EDUCAÇÃO INFORMAL: PROJETOS DE EXTENSÃO DO CENABIO/UFRJ NA PLATAFORMA INSTAGRAM
}

\author{
Semana Online Científica de Educação, 1a edição, de 25/10/2021 a 27/10/2021 \\ ISBN dos Anais: 978-65-81152-18-5
}

SANTOS; Mayara Vidal dos ${ }^{1}$, SILVA; Ronald Santos ${ }^{2}$, MACIEL; Eduarda de Souza ${ }^{3}$, LIMA; Renata Travassos de Lima 4, RAMOS; Isalira Peroba Rezende Ramos 5

\begin{abstract}
RESUMO
Introdução: A pandemia de COVID-19 ensinou à sociedade como a tecnologia pode aproximar e fragilizar ao mesmo tempo. Por um lado, ela aproximou 0 contato entre pessoas durante 0 isolamento social, imprescindível para contenção da disseminação do vírus. Por outro, foi ferramenta para circulação de informações sem fundamento científico. "Beba suco de limão!" “Tome ivermectina!". Foram tantas informações que se tornou difícil identificar o que era ou não "fake news". E, atualmente, observa-se que estudantes captam mais informações em redes sociais, do que em 45 minutos de aula. Logo, adaptar a forma de ensino é necessário e urgente. Se as mídias sociais se tornaram a principal fonte para buscar informações e divulgar ideias, então por que não criar perfis de referência nessas mídias? Objetivo: Analisar o uso das redes sociais como forma de educação informal e divulgação científica. Método: Análise de dados coletados pela equipe do projeto de extensão Conhecendo Cenabio - ciência, arte e educação no Instagram, a partir da recepção de acessos aos quadros Fatos ou Fakes e Cenabio Indica. Resultados e discussão: A página do Cenabio exibiu um aumento notável de 43,1\% de contas alcançadas, sendo das 564 contas, 63 não seguidores. Em relação ao perfil de usuários, 70,6\% eram mulheres e $29,4 \%$ homens. Por faixa etária, a maioria situa-se entre 18 e 44 anos $(80,3 \%)$, enquanto os jovens entre 13 e 17 anos compõem $1,0 \%$ desse público. Essa diferença pode ser explicada pela maioria dos seguidores serem usuários acadêmicos das plataformas no Centro Nacional de Biologia Estrutural e Bioimagem (Cenabio)/UFRJ. Isto representa um desafio ao Cenabio, que visa transmitir conteúdos científicos para estudantes dos ensinos fundamental e médio. Conclusão: O estudo demonstrou que o Cenabio possui um perfil consolidado no Instagram, todavia ainda necessita otimizar seus métodos para atingir o público-alvo e passar as mensagens desejadas.
\end{abstract}

PALAVRAS-CHAVE: educação, educação informal, divulgação científica, ensino, mídias sociais, conhecimento 